\title{
Philosophy, Violence, Metaphor
}

\author{
Jack Reynolds $^{1} \cdot$ Leesa Davis $^{1} \cdot$ Matthew Sharpe $^{1}$
}

Published online: 11 March 2016

(C) Springer Science+Business Media Dordrecht 2016

\section{Editorial Introduction}

If we did not stop to think, it would be easy (and veridical) to describe Ann Murphy's 2012 study Violence and the Philosophical Imaginary as an 'intervention' or an 'event' in philosophical studies in the continental tradition. But Murphy's book does what all good works of philosophy do. It makes us stop to think. It asks us to stand back from where we find ourselves. It prompts us, or at least those of us trained in a certain lineage of modern thought, to step out from behind the lenses through which we have come to see, and which have become almost invisible to us (Murphy 2012, 14).

As its title suggests, Murphy's work takes seriously the role of metaphor in philosophical work, and the shaping of the "imaginary" of specific philosophical traditions: their ways of talking, writing, speaking, even declaiming. 'So far, so good,' someone trained in the continental tradition might say - and indeed, Murphy's book is informed by a deep familiarity with the works of Derrida, Nancy, Lyotard, Le Doeuff and others within this tradition who have questioned the old philosophy-literaturerhetoric distinction. But Murphy's book, here drawing more specifically on Le Doeuff, is also a work that is animated by a desire to 'take stock' of the preeminence of violent metaphors to describe ostensibly non-violent phenomena, processes or objects in contemporary thought (117).

Rather than ignoring these phenomena, Violence and the Philosophical Imaginary sets out to 'think through what is at stake in the proliferation of these images' of violence (1). Far from being incidental to the main philosophical game, Murphy's claim is that images of violence have a literally transcendental, foundational role in many postwar continental thinkers' works. They become what Hans Blumenberg has called 'constitutive metaphors' for a subfield of inquiry, vital to conceptions of subjectivity, identity, representation and knowledge. These are each often conceived of as operating,

Jack Reynolds

jack.reynolds@deakin.edu.au

1 Philosophy Department, School of Humanities and Social Sciences, Faculty of Arts and Education, Deakin University, D5.17 Melbourne Campus, 221 Burwood Highway, Burwood,

VIC 3125, Australia 
on one side, through necessary and constitutive exclusions (whence 'violence'), and on the other, through the assimilation of alterity or difference to sameness (whence again 'violence') (20-22). There is an old Greek joke that he (or she) who does not philosophise still philosophises. If Murphy is right, there is a paradoxical sense in which he or she who does not wish to act or think violently nonetheless frequently invokes violent images. They might even be said to perform a kind of conceptual 'violence,' if we are to continue to use the kind of language that Murphy ask us to think critically about.

This guest-edited collection develops some of the themes that were first explored in a conference at Deakin University in November 2014. That conference was largely oriented around a visit by Murphy to discuss Violence and the Philosophical Imaginary and related subjects. Some of the essays included in this volume directly respond to her work, some take inspiration from it and for some Murphy's work was more of an indirect or oblique inspiration in that it informed the central topical idea of the event.

What then is the philosophical idea informing that event, and hence this guest-edited issue? No doubt contributors understood their remit in quite distinctive ways, but we have aimed to explore a series of questions concerning the connection between two or more of the titular themes: philosophy, metaphor and violence. Philosophy, of course, has always traded in metaphor, notwithstanding certain argumentocentric approaches that might seek to downplay this meta-philosophically and minimize metaphorical intrusions into philosophical work. One of our contributors, Marguerite La Caze (2002), has previously explored the significance of metaphor for the analytic tradition, despite at least some core trajectories of that plural tradition being wary of metaphor, and Murphy's book, as we have said, undertakes an intriguing analysis of the connection between philosophy and metaphors of violence in contemporary feminism and continental philosophy. Her analysis opens up a variety of questions that the contributions to this volume explore in regard to topics and resources in the history of philosophy that were not Murphy's own focus.

Essays included explore the role of metaphors of violence in various parts of philosophy, whether in Kant, Greek and Roman philosophy, Chinese Philosophy, Buddhist philosophy, in models of the extended mind and in meta-philosophical matters pertaining to both analytic and continental philosophy. Some authors implicitly criticize metaphors of violence in philosophy, while others seek to suggest that there may be some important reasons for persisting with them, in order to capture the 'real' that the philosophy is aiming to describe. There is then both a descriptive and normative interest here in the role of metaphor, and in the differing kinds of exclusion enacted in the name of philosophy more generally. Indeed, considerations pertaining to the role of metaphor in philosophy also open up other questions concerning meta-philosophy, i.e. what is proper to philosophy, and how it relates to the non-philosophical or pre-philosophical, and whether these relations are characterized by forms of what we might, hesitantly, call 'conceptual violence' - a conjunction that Murphy asks us to think more seriously about, in particular whether or not there is a kind of leveling that takes place in the generic deployment of references to, and images of, violence.

Murphy's own contribution begins the volume. Her article, 'Founding Foreclosures: Violence and Rhetorical Ownership in Philosophical Discourse on the Body', targets the omnipresence of violent metaphors in contemporary theoretical engagement with the theme of embodiment. Drawing on Susan Sontag and Eva Sedgwick's 'The Race 
for Theory', her concern is that the predominance of this metaphor in contemporary theorising may be foreclosing possibilities for non-violent understandings of corporeality, as well as of philosophical reflection itself.

In 'There is Not Just a War: Recalling the Therapeutic Metaphor in Western Metaphilosophy', Matthew Sharpe seeks to dispel some recent comparative philosophical writings proclaiming the centrality of violent and martial metaphors in Ancient Greek philosophy. Drawing on a work by Pierre Hadot and Martha Nussbaum in particular, and examples drawn from Plato's Republic and Plutarch's On Tranquility, he argues that medical metaphors are in fact at least as pervasive. Metaphilosophy lurks in the background here too, since Mattice's and Lloyd and Sivin's analyses, with which he takes issue, are framed by a comparative contrast between Greek and Chinese philosophy.

Despite its ostensible non-violence, Leesa Davis' contribution shows that images and metaphors of violence (and not always metaphorical, since they are also actual) play a significant role in Buddhist philosophy. In 'Enacting the violent imaginary: Reflections on the dynamics of non-violence and violence in Buddhism', she focuses on the recent cases of self-immolations in Tibet and the response from contemporary Buddhist leaders. Her paper highlights the dynamic interplay between violence and non-violence in Mahāyāna Buddhism and delineates ways in which metaphors of violence are both scripturally sanctioned and enacted in Buddhist thought and practice.

In 'Do no harm: the extended mind model and the problem of delayed damage', James Williams examines some of Andy Clark's recent work concerning the extended mind. Williams seeks to show that the harmonious coping with the environment that is presupposed in Clark's account of embodied and embedded cognition wrongly suppresses the disharmony at the basis of embodied life. As such, he also seeks to defend some metaphors of violence as being more appropriate than the engineering metaphors that feature in Clark and others and are oriented around ease of use.

Jack Reynolds begins from Murphy's argument that philosophy's identity and relation to itself depends on an intimate relationship with that which is designated as not itself (e.g. other academic disciplines and non-philosophy in general), the latter of which is a potential source of shame that calls for some form of response. In his paper, 'Philosophy's shame: reflections on an ambivalent/ambiviolent relationship with science', he argues that this shame is particularly acute in regard to the natural sciences in the nineteenth and twentieth centuries and that it has been a central contributing factor in the so-called analytic-continental 'divide'.

Antonia Pont's contribution, 'Keeping Secrets: Inflecting (Meta)ontology via Derrida's Three Levels of Violence', makes a comparison between two thinker's works who are often considered to be quite different, if not antagonistic: Jacques Derrida and Alain Badiou. Despite Badiou's different theoretical languages, notably his use of settheoretical categories, Pont tracks a parallel between three levels of violence operating in Derrida's post-structuralist account of the emergence of language and identity, and homologous claims in Badiou's account. Pont's article moves towards a Derridean criticism of the place of violence in Badiou's philosophy.

Valerijs Vinogradovs' piece, 'The Spectacle of the Guillotine via Kant's Judgement of Disgust and Aesthetic Ideas', moves from ontological to aesthetic concerns. He is interested in violence as an aesthetic spectacle and the aesthetic status of one fascinating episode of violence in the West's history: the decapitation of Louis XVI in 1792. 
Vinogradov first sets out an interpretative framework which would suggest positioning this spectacle of the guillotine as an aesthetic idea, in Kant's sense developed in the Critique of Judgment. His larger position in the paper, however, is to suggest that this moment of violence can better be seen as something like an aesthetic idol, one better met with loathing and dread.

Marguerite La Caze's article, 'The Language of Violence: Chiastic Encounters', is a powerful meditation on the relationship between language and violence. She elaborates on the Le Doeuffian argument that 'theorises the reversal of priority from violent language to the language of violence' by focusing on the similarities and differences of the language of violence of the Third Reich and the language of violence of the Rwandan genocide. In this analysis, La Caze exposes violent metaphors that are unfamiliar, highlights the ways in which violent metaphors have been incorporated into philosophical discourse and comments on the ways that euphemism and metaphor can both reveal and conceal. She concludes by stating that 'we should not only be attentive to violence in our own philosophical language but also be attentive to the acceptance of violent language in our global culture.'

Leesa Davis, Jack Reynolds and Matthew Sharpe 